\title{
THE RUSSIAN MARXIST CONCEPT \\ OF THE NATION: SOVIET DE-STALINIZATION PROBLEMS AND THE MAIN TRENDS OF ANTI-MARXIST REVISIONISM IN POST-SOVIET UKRAINE
}

\section{Vilkov V. Yu.}

\section{INTRODUCTION}

The process of creating the theory of the nation by the leaders of the Russian Social Democratic Labour Party (RSDRP (b)), its theoretical, political and ideological prerequisites, the authorship of the basic postulates, was revised and revalued many times in the Soviet scientific literature depending on the political leaders and elites who headed the USSR, as well as the specifics of the geopolitical processes of the twentieth century, the main ideological components of the official version of Marxism-Leninism, the prescripts of the programs and strategies of the ruling Soviet Communist Party. A great role was also played by the tendencies in the development of social, political sciences and cultural studies in the USSR and abroad in respect of the specifics of revision or attempts to modernize the axiomatics and the conceptual apparatus of the Marxist-Leninist theory of the nation.

A lot of works were dedicated to the problematics of the MarxistLeninist Theory of the nation in the USSR and far beyond its borders during the second half of the twentieth century (its name was also changed several times in Soviet social studies). Perhaps, the number of researchers and their works of different scientific status (monographs, anthologies, dictionaries, textbooks, articles, dissertations, etc.) and disciplinary nature (philosophy, political sciences, sociology, culturology, ethnology, psychology, etc.), where different problems of the Marxist conception of the nation were considered, or where the real facts of social life were analyzed from its ideological, theoretical and methodological standpoints, not only in the Soviet Union but also in the rest of the world, exceeds the number of researchers and their publications where other theoretical models (e.g., politics, economics, culture, spiritual life), that became a backbone element in the Marxist teaching of society, were the main object of the study.

Such high attention on the part of the Soviet scientific community and the party apparatus to the theoretical and practical problems of interpreting 
the phenomena of the national community and statehood, nationalism and internationalism, as well as interpretations of the processes of national genesis and nation-state building, the strategy of development of interethnic relations in the USSR and the nature of national relations in other countries (capitalist and developing), was predetermined by many interrelated factors, first of all, the scientific, political and ideological ones. The latter often became dominant in the system of requests and requirements for the social sciences and humanities in the second half of the twentieth century. It was they who determined the nature and direction of scientific research in the subject field of the theory of the nation, and had a decisive influence on the public assessments of scientists who specialized in the field of ethno-national problematics. The reasons for the ideologization of the research work of Soviet scientists and their accessible results (accessible to all citizens, rather than a limited group, especially in the 1980s), were that the theory and concept of the nation were of traditional interest not only for Marxism as a science. They also performed such important, for the political system and power in the USSR, functions as: the theoretical substantiation of the system of regulatory and legal statuses of ethno-national communities (nations, ethnic groups, ethnic minorities) in the Soviet Union; scientific apology of the party strategy of "bringing nations together under socialism"; the development and popularization in the mass consciousness of the ideology of the "new historical community" - "the Soviet people"; ideological, theoretical and methodological support for the propaganda work of the CPSU and its structures and, in general, the struggle of the institutionalized power of the Soviets against the manifestations of "bourgeois nationalism"; conducting counter-propaganda against all non-Marxist or anti-Marxist ideas, theories, ideologies and mythologemes that were created in the West and were considered hostile to the "matter of socialism and communist building", the victory of the national liberation movements of oppressed peoples, especially in developing countries.

\section{1. "Russian Marxist Theory of the Nation" by Joseph Stalin}

According to our estimates, it was the English scientist Antony Smith, the most famous leader in the research direction of the theory of nations and nationalism, who was the most critical and radical about the "scientific status" of the Marxist concept of the nation among the representatives of the modern (Western and post-soviet) scientific community. Firstly, he recognized Marxism as only one of the "four main directions of influence" (along with the concept of "crowd psychology" (first of all by Freud) - the teachings of Weber and Durkheim) on the process of formation of the 
paradigm of "classical modernism" in the system of modern theoretical knowledge of nations. Secondly, he emphasized that Marxism, like the other three directions, "concerned the analysis of nations and nationalism only peripherally". And he explained "the lack of interest in this issue" by the high probability of "conscious decision of both the founders of Marxism and their followers" to "marginalize cultural influence and the influence of the environment, concentrating on explaining the role of economic and class factors in the evolution of humanity". "In turn, this meant" that "in the framework of successive stages of historical development, ethnic and national principles and phenomena were inevitably assigned a secondary or even auxiliary role. At most, they were perceived as peculiar event catalysts or contributing (or inhibiting) factors ...”. After such research assumptions Antony Smith made a summary conclusion and issued a strong verdict, "Neither Marx nor Engels, Lenin nor Stalin, Luxemburg nor Kautsky, endeavoured to present a theory or model of nations and nationalism per se, not only because these phenomena were viewed with suspicion, if not outright hostility, even by those who conceded their political significance, but because the "science" with which they were concerned was intimately linked to a specific worldview and political strategy that sought to reduce all phenomena, at the explanatory level at least, to their economic basis, deriving cultural and political identities and movements from the class alignments thrown up by a specific stage in the development of the mode of production. It was in this context that the "formalism" associated with Marxist analysis became prominent: the idea that nations provided the forms and vessels, while class formations and their ideologies provided the content and ends to which the next stage of history aspired. This type of reductive reasoning has left a strong imprint on some latterday approaches to the study of nationalism, even where the theorists no longer accept the worldview and strategy in which it was embedded, and even when they eschew the cruder forms of economic reductionism and ideological formalism found in some of Marx's followers"1.

The Smith's highly negative assessments of the theoretical status of the Marxist interpretation of national genesis and the nature of nations will be left on his scientific conscience or civility. If we turn to the estimates of the alternative committed and ideological camp (to Marxists themselves), than it should be admitted that the Soviet Marxist-Leninist name of the theory

1 Smith A.D. Nationalism and Modernism. 1988. <http://milliyyet.info/wpcontent/uploads/2015/12/Anthony-D.-Smith-Nationalism-and-Modernism.pdf> (2019, September, 1). 
"Historical and Economic Theory of the Nation" is fully justified, since the axiomatics of the Marxist materialist understanding of history is ideologically and conceptually localized and its objective logic (common lows) of the development through the change of social and economic formations and the world-wide historical role of the driving forces of social transformations is conceptually reflected ("the subjects of the historical process", such as classes, peoples and nations). However, in the Soviet scientific discourse the name "Historical and Economic Theory of the Nation" was not historically original or politically and ideologically authentic. Since it was Joseph Stalin (in his work "Marxism and the National Question" (1913), on the basis of the fundamental criticism of the ideas of the Austro-Marxists Otto Bauer and Karl Renner, introduced the basic postulates of the Marxist concept of the nation and proposed such a definition, that the Soviet social scientists throughout the post-Stalin era, even in the wake of the anti-Stalinist moods in the 1950s and early 1960s, could not substantially "supplement" or "modernize") who, in 1929, gave it a clear name "Russian Marxist Theory of the Nation". Moreover, he categorically added, "There is only one option left, to recognize that the Russian Marxist theory of the nation is the only correct one",2.

The public introduction by Joseph Stalin of the term "Russian Marxist" can be explained by the fact that, perhaps, he was the first, among Russian social democrats, to develop a clear conception of the nation, which he contrasted with another influential trend in European social democracy Austrian Marxism, which had its own theory of the nation and a popular, in the early 20th century among many ideologues of national movements and left-wing parties, project of "cultural-national autonomy". Moreover, in 1929 there was no one to oppose to the head of the USSR and the CPSU (b), even in terms of terminology. Therefore, only a "faithful continuator of the Lenin's work" could afford to abandon his categorical political and ideological attitude, which he formulated in the appeal "To the Jewish Workers" in 1905, "The Party (RSDLP. - V.V.), to destroy any thought about its national character, gave itself the name not Russian, but Russia's"3.

2 Сталин И.В. Национальный вопрос и ленинизм. Ответ товарищам Мешкову, Ковальчуку и другим. Сочинения. М.: Государственное издательство политической литературы, 1951. . Т. 11. С. 335.

3 Ленин В.И. К еврейским рабочим. Полн. собр. соч. М.: Издательство политической литературы, 1979. Т. 10. С. 267. 
The name of the theory, called "Russian", perhaps, was the only thing that the multinational and "internationalist" scientific community of the Soviet era social scientists did not discuss publicly and could not borrow it under the "Stalin brand". In the literature of the second half of the 20th century, since the time of the "Khrushchev thaw", its mentioning was secretly tabooed. In numerous publications of that period on the "history of theories of the nation" (of a scientific and educational nature) the following stages were normally distinguished: "pre-Marxist ideas about nations"; "the scientific contribution of K. Marx and F. Engels to the development of its scientific, materialistic concept"; "the Leninist stage in the development of the nation's historical and economic theory" and "modern bourgeois theories", whose scientific value was always questioned in the USSR.

Undoubtedly, numerous and multifaceted publications of the classics of Marxism-Leninism (Marx, Engels and Lenin) allowed Soviet researchers to find additional arguments to recognize the priority of their ideas for scientific interpretation of national genesis and states, determine the essence of national entities and characteristics of their attributive traits and types, as well as assessing the role of nations in the political and cultural history of Europe and the world.

For this reason, after the end of the epoch of Stalin (during the 50s started the 60s) and within the framework of de-Stalinization requirements, Karl Marx, Frederick Engels and Vladimir Lenin were recognized by Soviet scientists and their colleagues from other socialist countries as the creators of the ideological, theoretical and methodological foundations of the MarxistLeninist theory, or as it was officially positioned during the 1960s -1980s, "the genuine scientific theory of the nation", as well as the authors of the basic political and ideological prescripts for the practical solution of the "national question". Indeed, the basic postulates of the historical-materialist interpretation were made in the numerous works of the classics of Marxism, both in the context of the axiomatics of the materialist socio-philosophical and politico-economical theory of society, and in the analysis of a purely national (theoretical and applied) problematics. They are as follows: the origin, essence, characteristics and typology of nations, the class dualism of national culture and identity; the relationship of nation and state (feudal, bourgeois and socialist) was revealed; a class assessment of nationalism and internationalism and their functions was given; policy regulations for the communist and socialist parties in the field of national politics were formulated; recommendations for the ideological support of socialist (proletarian) revolutions and national liberation movements, nation-state 
building in the first phase (socialist) of the communist socio-economic formation were proposed.

However, despite large numbers of works by the founders of Marxism and their followers (including the ideologist of the Second International, the leader of the German Social Democrats Karl Kautskiy), in which the genesis and social nature of nations, the essence and historical limitations of national states and nationalism were considered in various aspects (historical, economic, political, cultural, social, ideological, psychological, etc.), none of them proposed a definition of the national community. Only in the polemical and partially commentary works of Vladimir Lenin, who avoided the "definition game", there are fragmentary statements about such basic, from the point of view of social and philosophical teaching and political doctrine of Marxism, signs of nations as "unity" of "economic relations", "territory" and "language". The leader and ideologue of the Russian social democrats sharply criticized theoretical ideas of the nation, national culture and statehood of Austro-Marxists Otto Bauer and Karl Renner for "idealism", "psychologism" and "bourgeois nationalism", argued the political failure and danger of their project of "cultural-national autonomy" aimed at strengthening the international unity of the proletariat, the revolutionary social democratic movement, in order to destroy the national oppression in the bourgeois, albeit, formally legal, democratic and multinational state.

Thus, the theorist and ideological leader of the Austrian Social Democrats, the philosopher Otto Bauer, who openly positioned himself a as a follower of the teaching and methodology of the knowledge of Karl Marx, in his fundamental work "The National Question and Social Democracy" (1907), proposed the following definition, "The nation is a community of people connected with the unity of character on the basis of a common fate". He explained it very tautologically, "The commonality of fate means the joint experience of the same fate on the basis of constant relations and interaction". Such a community of life "operates in two directions". The qualities assigned by the nation on the basis of the community of fate are transmitted through natural heredity and through cultural inheritance, when "the cultural values created by the nation on the basis of the same community of fate are transmitted to another". For such a national community the unity of the territory and culture, and even the language is not obligatory (that is what Kautskiy was sharply criticized for). Otto Bauer's language was considered only a "tool" of culture, an "external regulator" of "social cooperation of individuals", unable to influence "cultural values" and, most importantly, "national character". From the socialist ideological position, the Austrian Marxist developed a political 
project of "cultural-national autonomy". Its essence was that by changing the "legal system" in a "multinational state" and transforming each of the national entities (as many representatives of any nationality living on the territory of the state) into a "legal entity" with the right of "taxation"; creating through "free statements of citizens" "National Cadastres"; conducting on their basis elections for autonomous and independent, in their decisions from central institutions, bodies of "cultural-national selfgovernment", which would be entitled to solve all the arising questions (in fact only humanitarian) of the vital activity of every nation (for example, the language of school education and publishing, as well as functioning of communes and counties, etc. $)^{4}$.

Another ideological leader of the Austrian socialists, the lawyer Karl Renner (also known as Rudolf Springer, Synopticus, since 1945 was the first president of Austria after the end of the Second World War), proposed a purely culturological definition. The nation, he stressed, "Is a union of likeminded and equally speaking people", it is nothing more than a "cultural community of a group of modern people not connected with a land". At the same time, in order to solve national problems in the contemporary bourgeois society, he declared it necessary to carry out not a political institutionalization of nations (an independent national state), but a political and legal project of "cultural-national autonomy". First of all, for the AustroHungarian Empire. The struggle for socialism of "different nations in Austria" he did not consider to be their primary task (declaring that it is relevant only for the "European" nations of "Germany, France and England"), or a way to solve the "national question". In his autonomist project, it was said that the initial principle or meaning of the "right of nationality" was, "Nationality must become one of the legal signs determining the state of a person", i.e. publicly declared by the individual "belonging to a nation" in legal terms should "be a part of the basic legal and public rights". Whereas each national community "should be constituted as a union of people on the basis of modern democracy, as an organization of legal defense",5.

To find a detailed analysis of the theoretical and political ideas of Otto Bauer and Karl Renner on the national genesis, the nature of the national

${ }^{4}$ Бауэр О. Национальный вопрос и социал-демократия. Санкт-Петербург, 1909. C. $25,115-119,132,135-139$.

5 Шпринер P. Национальные проблемы: Борьба национальностей в Австрии. Санкт-Петербург: Общественная польза, 1909. С. 43-44, 80-81, 111, 257-259. 
community, their typology, the draft resolution of the national question in multinational states, etc ${ }^{6}$.

And yet, Joseph Stalin in his work "Marxism and the National Question", was the first, among the theorists and ideologists of Marxism (both European and Russian), to offer a logically clear formula for the concept of the nation, which was conceptually related to the axioms of this doctrine. In 1913, this formula was published in an article style in three issues of the "Enlightenment" journal, which was edited by Vladimir Lenin, and who was well acquainted with its ideas, spoke well of it and recommended to the Bolshevik party organizations in Russia for review.

In this work, Stalin intended, as he noted, "to resist militant nationalism", whose "wave" was "threatening to capture the working masses". Having analyzed in detail popular among European and Russian Social-Democrats ideas of the Austro-Marxists, and analytically "exhausted", as he writes, "all signs" of the national community ("unity of language", "unity of territory", "unity of economic life and economic cohesion" and "unity of mental makeup"), which most political thinkers and ideologists of the second half of the 19 th, beginning of the 20th century considered typical of nations, he finally stated, "A nation is a historically constituted, stable community of people, formed on the basis of a common language, territory, economic life, and psychological make-up manifested in a common culture"7. It must be noted that this is a well-known part of the Stalin's definition. In addition, the author, debating with his ideological opponents of the time, and taking into account some possible prospects of an ideological struggle with antiMarxists (for example, if in modern terms, adherents of constructivism, inventionalism or primordialism), emphasized that, "Any nation is not an accidental or ephemeral conglomerate, but a stable community of people"; "A nation is not a racial or tribal, but a historically formed community of people"; "The nation, like any historical phenomenon, is subject to the law of change, has its own history, a beginning and an end"8.

Another important theoretical and doctrinal political idea of one of the ideologists of the RSDLP (b), which further influenced the national liberation processes in the Russian empire, especially lawmaking in the USSR and its initial legal regulations that determined the hierarchy in the

6 Вилков В.Ю. Западная нациология XX столетия: концептуальные портреты. История теорий нации и национализма. Saarbrücken: Lambert Academic Publishing, 2014. C. 6-74.

7 Сталин И.В. Марксизм и национальный вопрос. Сочинения. Т. 2. М.: Государственное издательство политической литературы, 1951. С. 293, 297.

${ }^{8}$ Там же. - С. 296. 
multinational federal state (cultural-national, national-territorial or union republican status), was the statement that "none of the indicated characteristics is enough individually exhaustive to provide a definition of the nation. Moreover, the absence, of at least, one of these signs is enough for a nation to cease to be a nation". In general, the categorical Stalin's theoretical and political answer, "Only the presence of all the signs taken together gives us a nation",

The Stalin's definition of the nation cited from the work of 1913, the formational framework of national communities and the interpretation of their basic features were almost undeniable dogma for the Soviet social scientists of the second half of the 20s -50 s of the 20th century. The Soviet scientists of later ideological epochs (1960s - 1980s) faced a difficult dilemma - to reject Stalin`s concept of the nation or significantly modernize it, and thus create a new anti-Stalin or counter-Stalin version of the definition of the nation, and not to abandon the systemically important postulates of the Marxist-Leninist teaching and the prescripts of the official communist ideology (which together turned into metanarration in the USSR) was impossible Stalin logically built up his interpretation of the essence of the national community on the axioms of the Marxist theory of society, its structure and development.

But before turning to the analysis and evaluation of innovations in the interpretation of nature and signs of the national community, which were made by the Soviet social scientists in the discourse of Marxism-Leninism and the CPSU history narrative in the second half of the twentieth century, it is necessary to recall our own Stalin's clarifications of the definition of the nation.

Therefore, in this case, of particular importance is the fact that the USSR scientists, in their intellectual searches and generalizations, took into account, as a rule, the wording of the text "Marxism and the National Question" (1913). And in fact, they did not take into account the very important ideas that were presented in the later Stalin's publication "The National Question and Leninism. The Answer to the Comrades Meshkov, Kovalchuk and Others" (1929).

In this publication, for analyzing and evaluating the evolution of theoretical ideas about the nature of nations in Soviet Marxism of the second half of the 20th century, two things seem fundamental. Firstly, Stalin himself corrected the meaning of the "fourth feature" of the national community ("psychological makeup, manifested in the unity of culture"), the

${ }^{9}$ Там же. - С. 297. 
interpretation of the name and the meaning, what caused great discussions among Soviet specialists during the 1960s - 1980s. Secondly, he categorically refused to recognize the state as the necessary "fifth" attribute/characteristic of the nation (national community).

Thus, in the definition that he edited in 1929, "the father of nations and the leading light of all sciences" emphasized, "Russian Marxists have long had their own theory of the nation". According "to this theory, a nation is a historically formed stable community of people that emerged on the basis of the following four features, namely, on the basis of a common language, common territory, common economic life and common psychological makeup, manifested in the unity of specific features of the national culture". In other words, Stalin himself changed the meaning of his own initial interpretation of the "fourth attribute". Although he did not present it in details $^{10}$.

At the same time, concerning the ideas of "statism", which opponents of Stalinist Marxism persistently offered to us in order to supplement the concept of the nation; its creator rejected them in a reasonable way. Such an approach can be recognized not only as a claim for the infallibility of the "faithful continuer of Lenin's work" in the theory of the "national question", but also by striving to make the Marxist understanding of the nature of the national community more ambiguous and precise, and politically more instrumental. It allowed preventing all the unnecessary controversy in the future (even non-public) in the Soviet scientific community and political class.

The essence of the problem was in the following. The Ukrainian scientists Froim Gorovskiy and Yuri Rymarenko who were influential in the scientific world of Soviet social scientists in their work, which was published in 1985, stressed, "In literature attention is payed to the wellknown evolution of the views of K. Marx and F. Engels on the interpretation of certain aspects and provisions of the general theory of the nation, and indicate, in particular, some of their adherence to the generally accepted statist theory, which placed the main emphasis on the "statehood» of national communities. K. Marx and F. Engels often used the term "nation" to denote a particular state in their writings, even if these peoples belonged to a

10 Сталин И.В. Национальный вопрос и ленинизм. Ответ товарищам Мешкову, Ковальчуку и другим. Сочинения. T. 11. Москва: Государственное издательство политической литературы, 1952. С. 333. 
slave-owning or feudal society, but retained some kind of common origin and language" 11 .

By the way, in his publications of the post-Soviet period, Froim Gorovskiy made Stalin's definition identical with the statist way of defining the concept of the nation. Contrary to the basic ideas of the Marxist historical and economic theory of the nation and, moreover, to the sense of his definition of the nation (including the list of its features of 1913) and, especially, the later additional Stalin`s explanations (1929), with which the Ukrainian scientist was familiar, he said, "Stalin's definition of the nation was the most damaging because it actually identified the national and state community. We can still feel its disastrous consequences today in the form of hypertrophic politicization of national relations" 12 .

So, Stalin, back in the late 1920s, on the proposal to improve "The Theory of the Nation of Russian Marxism" and "add one more attribute of the nation to the existing four", namely, "the existence of its own separate state", "without having which" "no nation can exist", replied, "I think that the proposed scheme with its new, fifth feature of the concept of the nation is absolutely erroneous and cannot be justified either theoretically or practically, or even politically"13.

Explaining his disagreement with the need to "supplement" and "correct" the "Russian Marxist theory of the nation", he said that theoretically such a scheme "leads to absurd conclusions" and "cannot be considered scientific". The leader of the Soviet Union, and the chief ideological theoretician of the Communist Party (Bolsheviks) wrote, "With your scheme, we would have recognized only those nations that have their own, separate from others, state, and all the oppressed nations deprived of independent statehood, would have to be blot out of the category of nations. Furthermore, the struggle of the oppressed nations against national oppression and the struggle of colonial peoples against imperialism would have to be removed from the concept of "the national movement" and "national liberation movement"14. He also stressed, "Moreover, under your scheme you would have to assert that Irish became a nation only after the formation of the Irish

${ }^{11}$ Горовский Ф.Я., Римаренко Ю.И. Марксистско-ленинская теория нации и социалистическая практика. Киев: «Вища школа», 1985. С. 18.

12 Горовський Ф.Я. Сталінське визначення нації. Мала енцииклопедія етнодержавознавства. Київ: Довіра: Генеза, 1996. С. 139.

13 Сталин И.В. Национальный вопрос и ленинизм. Ответ товарищам Мешкову, Ковальчуку и другим. Сочинения. Т. 11. Москва: Государственное издательство политической литературы, 1952. С. 334.

14 Там же. С. 334. 
Free State, and until that time they were not a nation"; "Norwegians were not a nation until the separation of Norway from Switzerland, but became a nation only after this separation"; "Ukrainians were not a nation when Ukraine was a part of Russia, they became a nation only after the separation from Soviet Russia at the time of the Central Council and hetman Skoropadskiy, but they again ceased to be a nation after they united their Ukrainian Soviet Republic with other Soviet republics into the Union of Soviet Socialist Republics. A lot of similar examples could be cited"15.

From a "practical and political" point of view, Stalin remarked that such a "scheme", firstly, "leads to the justification of national, imperialist oppression, the carriers of which resolutely do not recognize oppressed nations, nations that do not possess full rights and those nations that do not have their own individual states, and believe that this circumstance gives them the right to oppress these nations". Secondly, this "scheme leads to the justification of bourgeois nationalists in the Soviet republics", which "prove that the Soviet nations ceased to be nations after they went to unite their Soviet republics into the Union of Soviet Socialist Republics"16.

\section{De-Stalinization of the concept of the nation in Soviet Marxism in the second half of the XX century}

In the anti-Stalin epoch, especially during the 1960s, and the early years of the 1970s (and not only because of counter-Stalinism), but again in the second half of the 1970s, the first half of the 1980s, in the Soviet scientific community with the participation of researchers from European socialist countries, an active discussion among the representatives of various humanitarian, social and political sciences (philosophy, history, scientific communism, law, sociology, ethnography, cultural studies, social psychology, anthropology, etc.), took place on the problems of conceptual understanding of the phenomenon of the nation. One of its main reasons was to strive for either de-Stalinization or scientific modernization of the "historical and economic theory of the nation" through a more precise definition of the characteristics of the national community. That, respectively, required the development and introduction of a new scientific discourse, adequate to the social and political realities and ideological trends of the time, new its definition.

And above all, in the second half of the 20th century, the Soviet social scientists got engaged in the terminological correction of the Stalinist

\footnotetext{
15 Там же. С. 334-335.

16 Там же. С. 335.
} 
theoretical classification or designation of nations as "historically established stable communities of people". Most of them (each of these scientists maximally exploited the quotations of Karl Marx, Frederic Engels and Vladimir Lenin) stated in their publications that all communities of people (including the nation) are, without a doubt, "historical" and took an active part in the updating of the general noumenon (historical), initiating the tendency of using of ideas of theoretical sociology and ethnology. At the same time, they often unnecessarily played with the meanings and senses of the newly introduced concepts.

In their works, many of the Soviet researchers and their colleagues from the socialist countries began to insist that the nation is a binary "social and ethnic organism"17. Or "a social organism with which and on the basis of which nationality was formed and strengthened as a complex of characteristic ethnic features, attributes and specific qualities"18. Some authors (usually historians, social philosophers) changed their accents and offered to interpret nations as a "historical phenomenon", but above all as "social"19, which has a clear timeframe of being and formational (capitalism/socialism) features in the world history. A number of social scientists (mainly ethnographers, ethnopsychologists and philosophers) emphasized that national communities are a "historical social phenomenon" that "exists only in the ethnic form" $"$. Some of them, especially in the publications of the 1980s, proposed to consider national communities "in the contradictory duality of the social" (social-class) and "ethnic",21, and recommended appropriate names for them: "ethnosocial" or "socio-ethnic" community. In the early 1980s, under the influence of the works of the highstatus Soviet community ethnographers, the concept of "ethnosocial organism" was introduced into scientific circulation as one of the most common noumena for the national community ${ }^{22}$.

17 Куличенко М.И. Национальные отношения в СССР и тенденции их развития. Москва: «Мысль», 1972. С. 58.

18 Козинг А. Нация в истории и современности (Исследование в связи с историко-материалистической теорией нации). Москва : Издательство «Прогресс», 1978. С. 173.

19 Дашдамиров А.Ф. Нация и личность. Баку : Элма, 1976. С. 42.

${ }^{20}$ Калтахчян С.Т. Вступительная статья. Козинг А. Наџия в истории и современности (Исследование в связи с историко-материалистической теорией нации). Москва : Издательство «Прогресс», 1978. С. 7.

21 Иордан М.В. Национализм против интернационализма. Москва : «Наука», 1980. С. 69.

22 Бромлей Ю.В. Очерки теории этноса. Москва : «Наука», 1983. С. 63. 
Certainly, on the issue of the "correlation between ethnic and social-class in the national and the nation" and in numerous works by Soviet researchers, one can come up with theoretical approaches that are close to the above mentioned one.

In particular, the Ukrainian researcher Alexander Kuts, reproducing the point of view on this issue of his colleague, says, "However, one cannot but agree with $\mathrm{Yu}$. I. Rymarenko who writes that if there exist "two nations" in a bourgeois society in terms of social class, then in terms of ethnic there must be only one. No matter how acute the class struggle may be, it cannot destroy the "ethnic community"'. However, as a necessary accent, which is ideologically Marxist and theoretically correct, he further states, "In other words, one should take into account the existence of the national community and not forget that it consists of certain classes. As long as the society is class-divided, all relations in it, including the national ones, have a certain class content and require "scientific objectivity and their fundamental assessment from the standpoint of the working class", 23 .

A famous Soviet philosopher Hermann Glezerman, having supported the theoretical tenets, supplemented them with a key Soviet Marxist philosophical, political and ideological assessment, saying that, "a nation has known ethnic elements, which means, it consists of people belonging to certain ethnic groups or tribes that, in the process of forming a nation, had merged and formed a single whole"; "When the nation of a bourgeois society becomes socialist, ethnic elements are preserved". He stressed that "ethnic" or "national", even though it is borrowed when a bourgeois nation gets transformed into a socialist one, does not become dominant, "does not define" its "social appearance", culture, self-consciousness and psychology. Therefore, "on the basis of the new emerging (socialist. - V.V.) mode of production", a "radical change in the social nature" of national communities takes place ${ }^{24}$.

It should be noted that a number of ideas of the GDR academician Alfred Kozing was identical with the narrative and logic of the new Soviet theoretical and communist ideological attitudes in interpreting the ratio of "ethnic", "national", "class" and "social" (especially the division of nations into capitalist and socialist). Thus, he, saying that he agrees "with the point of view" of "nationality being an ethnic characteristic of the nation", expressed by the philosopher Suren Kaltakhchan, who was considered to be

${ }^{23}$ Куц А.М. Взаимосвязь классовых и национальных отношений в развитом социалистическом обществе. Харьков : «Вища школа», 1982. С. 13.

${ }^{24}$ Глезерман Г.Е. Классы и нации. Москва : Политиздат, 1975. С. 13-14. 
one of the leading experts in the "nation theory" in the USSR, and revealing his understanding of the phenomenon and the concept of "nationality" ("national affiliation", "identity"), using the example of the German Alsatians and Lothingians, who became an integral part of the French nation, emphasized that it is, in one case, an "objective characteristic". Unless, of course, "we are talking about national identity in the sense of belonging to a nation as a complex social organism that includes <...> of course ethnic identity" and "does not depend on how people determine their affiliation" (national, ethnic).

In the other case, "nationality affiliation/identity" is "only ethnicity belonging to one or another group of population with common ethnic features". And it is in this socio-historical dimension that "ethnic characteristic", ethnic similarity/community and "national identity", firstly, "passes from the feudal nationality to the capitalist nation in the process of historical development". Secondly, it is then inherited from the feudal and bourgeois past by socialist nations. In general, the "nationality", as a combination of only ethnic features (including identity which is based on them), claimed the German academic, may be the same, but nations as objective historical communities (even with one ethnic/national identity) are often different. For example, "the German socialist nation in the GDR" and "the German capitalist nation in the FRG" 25 .

At the same time, in the work of the Academician of the Academy of Sciences of the GDR, Alfred Kozing, along with the joint opinion, in the context of the paradigm ideas of the Soviet Marxists about the relationship between the social and ethnic, the most generally understood as a "form of national community", as a "concrete form of its social content" or "social essence" and that a nation, as a historical form of the community of people differs mainly from other large and historical stable forms of communities (social groups) - ethnic groups, nationalities, classes, social strata, castes, ethno-confessional groups, etc., a rather non-standard social-politicalphilosophical idea for the Soviet Marxism-Leninism was expressed (published in the USSR in 1978). Actively quoting Vladimir Lenin, like all Marxists, he, but in his own way interpreted Lenin`s axiom, "Nations are an inevitable product and an inevitable form of the bourgeois era of social

25 Козинг А. Нация в истории и современности (Исследование в связи с историко-материалистической теорией нации). Москва : Издательство «Прогресс», 1978. С. 164-165, 172-173, 175-177. 
development" 26 , and argued that they (nations) are not just a form of community (collectivity, or a large social group) of people of a certain, postfeudal period of history, but something more. He stressed, "In both socioeconomic formations - the capitalist and socialist, nations is first and foremost a natural form of the development of society". "A nation is a form of development of social existence that continues to exist even after the liquidation of capitalism and plays an important role in the historical development of society" 27 .

On the assumption of such a general sociological message that equates "community" and "society", but without taking into account the fact that nations are not the only "social product" of social development processes even under capitalism, the German scientist made quite radical theoretical and political (because he did not take into account the institutional aspect of national reality, that is, the forms of state structure existing in the world and the nature of globalization processes) conclusions. He stated that a "bourgeois society naturally develops in a national form", and a "socialist nation" is "a form of development of a socialist society"

However, such a theoretical novelty remained almost unnoticed among Soviet social scientists and did not affect the process of modernization done by them of the historical and economic, Marxist-Leninist theory of the nation.

In general, the main trend in the course of de-Stalinization (revision) of the Soviet Marxist-Leninist theory of the nation and its basic concept was that scientists began to treat "ethnic" not as the essence of a nation, but only as its "socio-historical uniqueness", or "universal historical form or method of organizing its content". And on the contrary, the social in a nation was recognized by them as its essence, substantiality, qualitative certainty which manifests itself in the ethnic form, but completely depends on the class nature of nations. It is the social and class essence of a nation, all social scientists and humanities tirelessly repeated, that influences its political institutionalization, the type of ideology, the society dominating values (nationalistic or internationalist) and the character of cultures (bourgeois, democratic or socialist).

26 Ленин В.И. Карл Марс. Полн. собр. соч. Москва: Издательство политической литературы, 1977. Т. 26. С. 93.

27 Козинг А. Нация в истории и современности (Исследование в связи с историко-материалистической теорией нации). Москва : Издательство «Прогресс», 1978. С. 120, 124.

28 Там же. С. $121,125$. 
It should be especially mentioned that active discussions and innovations in the interpretation of the essence and dialectics of the interrelation of the phenomena and concepts of "ethnic", "ethnicity", "nationality", "national affiliation" and "national identity" in the human and social sciences in the USSR in the second half of the 20th century were not only preconditioned by the internal factors of their development.

A major role was played by external challenges and requests. Firstly, the rivalry with Western researchers and their latest theoretical models of nation and nationalism, many of whom actively used the above-mentioned concepts in their theories. The most fundamental question was, precisely, the definition of the essence of "ethnic" and "social" and their correlation in the national and the nation. Moreover, their objective content, as well as subjective (national: consciousness, self-consciousness, identity, identification, psychology, feelings, etc.) manifestations, structure and functions were also important. Secondly, the problematics and themes of the relationship between "ethnic" and "social" turned out to be extremely relevant not only for the purpose of further updating the Marxist-Leninist, historical and economic concept of the nation, but also because of the need to develop theoretical foundations for the Communist Party ideological innovations stated in the early 1960s. And above all, the main idea of the new ideologem and mythologem, which were proclaimed in 1961 at the XXII Congress of the CPSU in the report by Nikita Khrushchev, was that from the representatives of different nationalities (nations, ethnic groups, etc.), a "new historical community of people - the Soviet people", was formed in the Soviet Union.

Over time, this "type of consolidation of the people" (in modern Western literature, the concept of the "civic nation" is used for this phenomenon, i.e. liberal and democratic interpretation of the political national community. It is conceptually defined as a solidary political and legal community of equal citizens of a democratic state (a republic where the principle of "sovereignty of the people" is guaranteed constitutionally), whose identity is not ethnic, but political. Its mental and ideological core is not ethnonationalism, but patriotism, as well as the principles and values of multiculturalism) ${ }^{29}$ was interpreted in the literature by the Soviet scientists not only as historical, but

29 Вілков В.Ю. Генезис поняття нації. Видання 3-ге. Київ: Видавець Карпенко В.М., 2014. С. 317-322; Вілков В.Ю. Ідеологема та міфологема «Національна ідея»: українська політико-філософська традиція в дискурсі сучасної теорії демократії (частина друга). Wspótpraca Europejska. 2018. № 5 (36). C. 10-22. 
also as a social and international community, which is characterized by: state-political and territorial unity (with a federal, union structure), common socialist economy, uniform in social peculiarities and diverse in national characteristics culture, strong socio-political and ideological (based on Marxist-Leninist ideology, communist ideals and goals, principles of internationalism, Soviet patriotism, the policy of strengthening the friendship of peoples done by the CPSU) inviolable unity of all classes, domains, nations and nationalities who, like a "family of the peoples of the USSR" under the influence of the socialist system and the Soviet political system, developed a common cultural way of expanding the sphere of the use of the language of international communication (Russian), values and features of the nation's psych.

For example, here is one of the standard definitions of the "Soviet people", which is given in a typical textbook (1981) on "Scientific communism", which, we remind, in the 1960s became a generally obligatory discipline in the system of higher education of the Soviet Union. "The Soviet people", stated the authors of the textbook, as well as the academicians and first figures in the formal and informal hierarchy of the Soviet community of social scientists and ideologists (Peter Fedoseyev, Viktor Afanasyev, Fedor Burlatskiy, Alexander Yakovlev, Vadim Zagladin, Suren Kaltakhchian and many others), "is a community of people that has one common homeland, common territory, one single economy that is based on social property, one single culture with socialist content and diverse in national characteristics, national languages and a language of international communication, common federative state and one common goal - building of communism.

The Soviet people represent a single collective of workers from cities and villages of the multinational USSR. The socialist social system gave rise to new psychology and a new spiritual image of the Soviet people. In their activities, they are guided by Marxist-Leninist ideology, the communist ideals of the working class, and the principles of proletarian and socialist internationalism.

In the formation of a new historical community of people - the Soviet people, the leading role was played by the CPSU..."30.

Of course, in terms of its content, the above definition of the Soviet people is, to some extent, similar to the Marxist-Leninist definition of the nation.

\footnotetext{
${ }^{30}$ Научный коммунизм: учебник для вузов. 5-е изд. Москва: «Наука», 1981. C. 320 .
} 
For this reason, in order to somehow operationalize the difference between the meanings and senses of these two concepts, in literature one significant theoretical clarification was given to its ideological pathos and stereotypes, "The Soviet people is not some kind of supernation that assimilates and replaces nations, but their international community"; its "social, ideological and political unity, integrity", which "functions as a complex international system, the structural elements of which are socialist nations and nationalities"; "the systemic organization of people of different nationalities". The Soviet people is a community of people "of a higher order than a nation". "The interaction of the national and the international occurs within" this "social and international community" and "is the source of the flourishing and rapprochement of the nations and nationalities of the $\mathrm{USSR}{ }^{31}$. By the way, such a distinction between the phenomena and concepts of the "Soviet people" and the "nation", which was clearly carried out in the end of the 1980s, at least in theory and ideology, shows the illegality of a number of analogies and critical assessments that were stated in the post-Soviet period. For example, the Ukrainian researcher, George Kasyanov, relying on the Western terminological and ideological tradition which was formed in the complex of paradigms of the theories of the nation and nationalism, said, "Although it is paradoxical, the development of the concept of "a new historical community" led to the formation of ideas of the so called political nation. At the same time, the term "nation", obviously, should have been out of use, instead, a politically more neutral term "the people" was put forward. In fact, the term "Soviet people" was synonymous with the term "political nation" 32 .

It is worth reminding that following great discussions, the Soviet social scientists also agreed that the "four features" (social and ethnic) of the national community that are classical for Marxism (common territory, economic life, language and psychological makeup manifested in the common culture) are necessary and sufficient to determine the nation. And some logical corrections of the features, proposed by many of them, were insignificant.

Even less scientifically significant and theoretically reasoned in the Soviet period of the $70 \mathrm{~s}$ and $80 \mathrm{~s}$ of the last century were the recommendations of the scientists to proofread the names of the main ("four") features of the nation. The first of them, ("common language" in its

${ }^{31}$ Там же. С. 321.

${ }^{32}$ Касьянов Г.В. Теорії нації та націоналізму: монографія. Київ : Либідь, 1999. C. 48. 
original version) was proposed to be interpreted as "common literary language", "homogeneity of language", "unity of written language". The second was offered to rename: "the unity of the territory", "the integrity of the territory". The third basic feature of the nation, as well as the two previous ones, did not cause any particular objections on the part of the Soviet social scientists, but it was suggested to clarify its meaning like this: "commonality of economic relations" or "commonality of industrial economy".

The most heated theoretical debates among Soviet researchers arose on the issue of understanding the essence (including structural elements) and the name of the "fourth" Stalin's characteristic of the nation - "The unity of mental makeup", manifested in the cultural affinity. And the problem of the theoretical modernization of this feature was generated in the Soviet scientific community not only by the complexity of the social and philosophical understanding of the subjective, social, psychological and mental constituent of all the processes of national genesis, national liberation or unification movements and nation-building, but also by the disciplinary differentiation and underdevelopment of the categorical apparatus (tools) of the set of "science of the spirit".

As a result, by the early 1980s, from the set of ideological and conceptual innovations to replace the outdated Stalin's name "mental makeup", in the discourse and the logic of the ideas of the Marxist-Leninist theory of the nation, which was influenced by the work of such iconic figures in the Soviet system of human and social sciences as Edward Bagramov, Yuri Bromley, Ahmed Gadzhiev, Afrand Dashdamirov, Leocadia Drobizhieva, Suren Kaltakhchian, Michael Kulichenko, to designate "the spirit and soul of the nation" as the subject of cultures and politics the following categories became dominant in the Soviet scientific literature: "national character", "national psychology", "national consciousness" and "national selfconsciousness" (at the same time, we need to stress that the concept of "national identity", which is more characteristic of the conceptions (theoretical models) of the nation and nationalism of Western researchers, has hardly been used).

Of course, each of the Soviet researchers, depending on his sectoral or disciplinary membership, his own theoretical ideas and preferences, sought to modify the interpretation of the essence, structure, socio-political and cultural functions of the above-mentioned mental phenomena. Thus, one could correct the meanings and senses of the concepts traditional for the Soviet Marxist-Leninist theory of the nation. There were those who rejected all sorts of innovations, even lexical ones, tried to prove the "non-scientific 
status" of such a "novelty". And some, contrary to the "collective voice", formed in the scientific community, unsuccessfully, but with the help of a complex, as a rule, "scientific-like" argument, tried to introduce into the scientific circulation their own non-standard ideas and concepts for the theoretical reflection of the spiritual side of the existence of nations.

On the other hand, the collective Soviet modernization of the MarxistLeninist ("Russian Marxist") theory and concept of the nation did not lead to borrowings from its ideological opponents, did not take steps to come closer to the paradigmatic theoretical models that were created by Western scientists in the second half of the 20th century on the basis of axiomatics and methodologies of various social sciences. Certainly, they became known to the representatives of the Soviet Union scientific community, but were criticized by them because of their conviction or even because of the totality of the Communist Party "voluntarily-compulsory" control. Although, it was mostly done, not from theoretical, but from political and ideological standpoints. And above all, the Soviet Marxists rejected the innovative, heuristic ideas of those modern approaches and concepts whose authors developed the dichotomy of nationalism, national communities and identities as ethnic and political phenomena.

The definitions, that became classical by the mid 80s of the last century in the USSR, says a lot about the rejection of Western experts in the field of "theories of the nation and nationalism", as well as the modernization of the "Russian Marxist" (Marxist-Leninist) theory of the nation and its basic concept. Thus, in the high-status and exemplary for the Soviet times scientific publication - "Philosophical Encyclopedic Dictionary" (the article was written in 1983 by Suren Kaltakhchian), the nation was defined as "a historical community of people formed during the formation of the unity of their territory, economic ties, literary language, some features of their culture and character",33.

\section{Trends in the revision of Marxist-Leninist theoretical model of the nation in social, philosophical and political studies in post-Soviet Ukraine}

In the second half of the twentieth century, in the Soviet scientific and educational literature for the system of higher and specialized secondary education, social scientists and, first of all, the representatives of the scientific community of philosophers and political researchers, classified the

${ }^{33}$ Калтахчян С.Т. Нация. Философский энцииклопедический словарь. Москва: Сов. Энциклопедия, 1983. С. 417. 
Marxist conception of the nation as "historical and economic". They proved that this conception, unlike all theoretical models that were created by the Western scientists, is considered to be scientific and true to life, expresses and upholds democratic values.

However, in the publications of Russian and Ukrainian authors attitudes changed. It happened in the post-Soviet period. Being "historical and economic", the Marxist interpretation was considered as one the of several main paradigms (approaches, theoretical models, conceptions) in the system of modern theoretical knowledge about the nations and nationalism, which retains scientific influence and has a practical value, but in the world of science (outside the post-Soviet intellectual space) it does not have a competitive advantage over the political, psychological, cultural and ethnic theories of the nation, developed by the Western researchers during the second half of the $20^{\text {th }}$, beginning of the $21^{\text {th }}$ centuries.

Especially actively this idea was proven by Ukrainian social scientists. It was first offered in the article called Nation in the scientific collective edition named "Interethnic Relations. Terms and Definitions: Dictionary", and was published in Ukraine in 1991 a few months before the demise of the USSR. Its authors, Froim Gorovskiy, Alexey Kartunov and Yuri Rimarenko, the well-known experts in the theory of the nation in the Ukrainian Republic and the USSR, categorically stated, "The existing definitions of the nation can be roughly subdivided into four large groups: psychological, cultural, ethnological historical and economic" ${ }^{34}$. The same authors repeated a similar statement in 1996 in such a fundamental publication for Ukraine as Short Encyclopedia of the Ethno-State Science (Nationhood and Statehood) ${ }^{35}$.

Later, A. Kartunov in his publication (1999 and 2007) expanded and corrected the list and names of the main theoretical models, respectively, the approaches to the definition of national community, highlighting the political (in other generally accepted terms - the statist model), cultural, psychological, ethnic, historical and economic (i.e., the Marxist) theories or concepts of the nation ${ }^{36}$.

${ }^{34}$ Горовский Ф.Я., Картунов А.В., Римаренко Ю.И. Нация. Межнациональные отношения. Терминь и определения: Словарь справочник. Киев, 1991. C. 45 .

Горовський Ф.Я, Картунов О.В., Римаренко Ю.І. Нація. Мала енциклопедія етнодержавознавства. Київ: Довира: Генеза, 1996. С. 121-122.

36 Картунов О.В. Вступ до етнополітології: навчальний посібник. Київ, 1999. С. 131-142; Картунов О.В. Західні теорії етнічності, нації та націоналізму: навчальний посібник. Київ: Університет економіки та права «Крок», 2007. C. 56-71. 
It should be especially mentioned that some Ukrainian leading experts in the field of studying the history of theoretical ideas about the nation in the publications of the late 1990s, referring to the statements done by their Western colleagues, began to popularize the opinion that the independent "Marxist-Leninist historical and economic theory of the nation" had not been created. For example, George Kasyanov said, "According to many modern researchers (B. Anderson, T. Bottomor, R. Debre, Oras B. Devis, N. Pulantsas, and others), "traditional" or orthodox Marxism did not have its own theory of the nation at all" 37 .

Another authoritative Ukrainian scientist A. Kartunov, in his publication for the general reader (in textbooks), relying on the statements of the Western researchers (Walker Connor, Alfred Low, Charles Herod) and the assessments of some Ukrainian specialists in the history of theories of the nation, and by accusing Stalin of direct borrowing of the key ideas in interpreting the essence of the national community from the works of Karl Kautskiy (and, ostensibly without mentioning their authorship), called this German social democrat the developer of the "historical and economic (i.e. Marxist $-V . V$.) theory of the nation"38.

By the way, the Ukrainian scientists Froim Gorovskiy, Alexey Kartunov and Yuri Rimarenko were among the first, who, in 1991, at the time with the already obvious collapse of the USSR, showed sharp but not very reasoned criticism of Stalin`s definition of national community and, above all, in the aspect of its theoretical "innovation" and political mission. They stated that in this theory I. V. Stalin, first of all, "relied on the provisions of K. Kautskiy and partly of O. Bauer". Secondly, in spite of the fact that his "theory of the nation was different from the standpoints of K. Marx, F. Engels, V. I. Lenin, and K. Kautskiy", nevertheless, he "committed a forgery", because he borrowed "some features" of national community that were formulated in the writings of the "founders of Marxism and Lenin", and then "included" them in his "definition of the nation", but "gave them their own, dogmatic interpretation, which was absolutized, hypertrophied and linked them to each other rigidly". He then emphasized that only unity, only the presence of all the features "combined together gives us a nation". Third, the researchers reminded that in the work The National Question and Leninism (1929), the

${ }^{37}$ Касьянов Г.В. Теорії нації та націоналізму: монографія. Київ: Либідь, 1999. C. 49.

38 Картунов О.В. Вступ до етнополітології: навчальний посібник. Київ, 1999. С. 138-139; Картунов О.В. Західні теорії етнічності, нації та націоналізму: навчальний посібник. Київ.: Університет економіки та права «Крок», 2007. C. 65-66. 
Soviet leader "introduced the division of nations into capitalist and socialist". Finally, they concluded that, on the whole, "Stalin's approach" to the definition of the nation "was not accidental". For, on the one hand, "it was due to the absolutization and hypertrophication of the place and role of the class principle, the class struggle in the political life of society, and the underestimation and ignoring of the national factor". On the other hand, he (Stalin`s approach) "laid a theoretical foundation for the politicization of nations, their identification with the state and transferring the characteristics of a separatelautonomous political system". Thus this foundation allegedly "led to the inequality of ethnic groups, their artificial division into "state nations" and "non-state" nations",39.

Identical detailed criticism was repeated by the same authors in the Nation article in the publication called "Ethnonational Development of Ukraine. Terms, the Definition of Personality" (1993). Although the accusations of Stalin of "forgery" lost the scientific logic. Since, on the one hand, it was stated, "As it is known, neither the founders of Marxism, nor Lenin did not give a definition of the nation. They only ambiguously mentioned some of its features, in particular: common territory, economic relations, language and culture". And, on the other hand, the Ukrainian researchers actually stated that Stalin committed forgery in relation to those who could not define the nation in the framework of the Marxist paradigm and only ambiguously stated that there were some common features of national community. And what did he replace in the nonexistent and indefinite? The authors wrote that the essence of this forgery "laid" in the fact that "by having included the mentioned features in the definition of the nation, he gave them his own, dogmatic interpretation, absolutized, exaggerated and rigidly tied to each other" ${ }^{\prime \prime}$.

After the final change of social, political and ideological epochs in Ukraine (from "pseudo-socialist" to "pseudo-democratic"), many prominent Ukrainian scientists stepped up criticism of the ideas and theoretical constructions of Joseph Stalin. In particular, the same F. Gorovskiy (in such a fundamental, collective and unique publication for the post-Soviet scientific communities as Short Encyclopedia of the Ethno-State Science, 1996) said that the "Stalin's definition of the nation is of a compromise

39 Горовский Ф.Я., Картунов А.В., Римаренко Ю.И. (1991). Нация. Межнациональные отночения. Термины и определения: Словарь справочник. Киев, 1999. С. 46-47.

40 Горовський Ф.Я., Картунов А.В., Римаренко Ю.И. Нація. Етнонаціональний розвиток України. Терміни, визначення персоналії. Київ, 1999. С. 251-252. 
nature, since it eclectically united historical, economic and psychological views on the nature of the phenomenon of the nation itself'. In addition, F. Gorovskiy emphasized, "With a careful analysis it is not difficult to notice that the first three signs of the nation are given by Stalin "the way Kautskiy did it", while the fourth is taken from Bauer" ${ }^{41}$. In this case, we note that in the works of Karl Kautskiy, who sharply criticized the theory of the nation and the project of cultural-national autonomy of Austro-Marxists Karl Renner and Otto Bauer (especially the latter, because he did not understand the essence of national culture, progressiveness in the capitalist era of such a form as a "national state" compared to a "state of nationalities", considered Jews to be "a nation that has no future" and therefore does not need culturalnational autonomy), defined attributive, for social and political philosophy of Marxism, features of the national community (especially the historicity of its nature, an unconditional necessity for the formation of the nation of "community of language" and "territory"), nevertheless, did not suggest a definition for it.

A similar assessment, but with an additional emphasis on the fact that the Stalin's definition is a "plagiary", was offered by A. Kartunov in his textbooks ${ }^{42}$. G. Kasyanov did the same but more tactfully by giving a reference in his monograph (1999). This way Stalin received a new accusation of non-Marxism. "It is not difficult to notice", he stressed, "that Stalin in some elements of his synthetic definition appears to be a real "Veberian", although being an orthodox Marxist, he introduced a very important element in it "the unity of economic life" (in this respect he appears to be not so much Marx, who had little interest in the issues of nations in general, but the German thinker Friedrich List, who was one of the founders of the economic theory of the nation)". In general, as a result of the analysis of the Russian-Soviet Marxist approach to the conceptual modeling of the nation's phenomenon, George Kasyanov stated, "If we turn to taxonomy, then it should not be called "Marxist-Leninist", but "MarxistStalinist" or, for example, "Marx-Stalin-Kautskiy-Renner" (the list goes on)". Although he still admitted, "Some parts of it, if perceived not as a canon, but as a more educational means, seem to be quite correct and interesting for the researchers of the question of the nation, therefore you

41 Горовський Ф.Я. Сталінське визначення нації. Мала енцฺиклопедія етнодержавознавства. Київ, 1999. С. 139.

42 Картунов О.В. Вступ до етнополітології: навчальний посібник. Київ, 1999. С. 139; Картунов О.В. Західні теорії етнічності, нації та націоналізму: навчальний посібник. Київ: Університет економіки та права «Крок», 2007. С. 66. 
should not treat it as an "ideological trash", what some modern researchers suffer from" ${ }^{\text {, } 3}$.

Finally, it is necessary to recognize that in the situation of a radical change of political systems and ideological doctrines that occurred in the new independent states, many scholars in their interpretations of sociopolitical phenomena and processes that were related to national problems, were often driven not by strictly scientific, scientistic theoretical and methodological criteria, attitudes, arguments and requirements, but by political sympathies, ideological preferences and conceptual eclecticism.

In the theoretical aspect, the definition proposed by leading Ukrainian specialists (F. Gorovskiy, A. Kartunov and Yu. Rimarenko, 1991) were one of the most visible manifestations of the consequences of the processes noted above. They stressed that "a category of nation could be defined as an ethno social (and not always blood-related) community with the existing stable self-awareness of its identity (common historical fate, psychology and character, adherence to national material and spiritual values, national symbolism and national ecological feelings), as well as (mainly at the stage of formation) territorial, linguistic and economic unity, which later under the influence of integration and migration processes manifests itself ambiguously, often losing its decisive significance, but by no means does not disappear. Due to various life conflicts, national unity can be maintained, both materially and for a number of nations, by spiritual and psychological factors, in particular, by common origin and historical destiny"

Another example, as one more characteristic feature of the post-Marxist stage of the development of theoretical models of the nation, which implicitly began to form in the USSR in the late 1980s and became one of the determining factors after its collapse, was the tendency to interpret the national community. Firstly, it was done on the basis of very abstract ethnological and ethno-psychological ideas (in the latter case, even the nineteenth century), and secondly, not to include in the definition of the nation a list of its specific features. For example, the definition of the nation that is proposed in such a Russian edition as "Politology: An Encyclopedic Dictionary". The dictionary defines nation in the spirit of the ethicist interpretation with some elements of agnosticism, "A nation (from Latin.

${ }^{43}$ Касьянов Г.В. Теорії нації та націоналізму: монографія. Київ : Либідь, 1999. С. $46,49$.

${ }^{44}$ Горовский Ф.Я., Картунов А.В., Римаренко Ю.И. Наџия. Межнациональные отночения. Термины и определения: Словарь справочник. Київ, 1999. C. 49 . 
Nation - tribe, people) is a type of ethnos, a historically arising socioeconomic and spiritual community of people with certain psychological make-up and self-consciousness. It is so complex in content and diverse in its specific rules that it is impossible to embrace it with a general, formal definition, without distorting its essence, without leaving aside many essential characteristics and features" ${ }^{\prime 45}$. Another even more pro-Marxist definition, although with the active use of postulates from the Western theories of ethnicity, as well as psychological interpretations of the phenomenon of the nation, was offered in the collective work of Ukrainian scientists "Politology Encyclopedic Dictionary: higher educational establishment students manual", in which the authors noted, "A nation (from Latin. A nation - tribe, people) is a type of ethnos, a socio-economic and spiritual community of people with a certain psychological make-up and consciousness, the occurrence of which was predetermined historically and which has a persistent aggregate of essential characteristics"46.

Another innovative post-Marxist tendency of the last 20 years in Ukraine, which has not yet produced significant results, was the numerous attempts of Ukrainian specialists in the field of theoretical knowledge of the phenomenon of the nation, the national idea, the processes of national and national-state building (some ideologists of political parties and movements joined them) to develop the concept of "Ukrainian political nation". Moreover, they tried to create such a term or conception, as a rule, not on the ideas, political and ideological principles or legal recommendations of modern Western liberal-democratic doctrines and teachings, i.e. not as a model of a "civic nation" (for example, similar to the concept of the German political scientist, Otto Dunn and the Canadian researcher, Will Kymlicka), but exclusively on the ethicist (sometimes even radically nationalistic or ethnocratic) ideas about the national community and nationhood, as a model of a homogeneous, mono-ethnic nation ${ }^{47}$.

45 Политология: энциклопедический словарь. Москва : Издательство Московского коммерческого университета, 1993. С. 212.

46 Політологічний енциклопедичний словник: навчальний посібник для студентів вищих навчальних закладів. Київ.: Генеза, 1997. С. 222.

47 Вилков В.Ю. Западная нациология ХX столетия: концептуальные портреты. История теорий нации и национализма. - Saarbrücken: Lambert Academic Publishing, 2014. С. 199-226; Вилков В.Ю. Нации и национальная государственность. Очерки истории социально- и политико-философской мысли. Saarbrücken: Lambert Academic Publishing, 2017. С. 27-121; Вілков, В.Ю. Неоліберальна концепція нації та національно-державного будівництва Вилла Кимлічки. Вісник Київського національного університету імені Тараса 
As for the prospects of the Marxist-Leninist theory of the nation (i.e. the historical and economic version of the interpretation of the system of nationforming traits), now, as a result of the official or unofficial (personal author) decommunization, it has practically lost its political relevance, influence and significance in the post-Soviet space, including Ukraine. The general situation among the scientific communities of the post-Soviet states, which study the theoretical aspects of national problems, was that most of their representatives were completely reoriented towards the intellectual product created by Western researchers in the field of theoretical modeling of the phenomena of nations and nationalism. In fact, many modern social scientists stopped independent scientific research and retrained to popularize basic non-Marxist paradigms (primordialism, modernism, perennialism, ethno-symbolism, inventionalism, etc.).

Moreover, some of the most influential theorists in both Soviet and postSoviet times, in particular, Ukrainian (G. Kasyanov, M. Stepyko) and Russian (V. Tishkov, V. Malakhov, A. Kustarev), following the well-known Western authorities in the theory of nation and nationalism (for example, such as B. Anderson, P. Alter, R. Brubaker, E. Carr, F. Hertz, K. Minogue, J. Summers, K. Symmons-Symonolewcz, H. Seton-Watson, P. White, etc.), became vocal supporters of either constructivism (especially of the postmodern, cognitive and linguistic type), or adherents of the "paradigm of strategic relativism" and agnosticism. They openly proposed to abandon both, the notion of "nation" and any scientific theoretical modeling of the phenomenon of national community, the definitions of its main features, the understanding of its institutionalization processes, etc. ${ }^{48}$. They argued that that there had long been a fundamental and insoluble problem of the "definition uncertainty" in the complex of national sciences (unlike many other social, especially natural, branches of knowledge). Its essence is simple and lies in the fact that even in the medium term there are no scientific and theoretical prerequisites and opportunities to formulate a definition of the nation that could become universally accepted and common to all scientist, at least within the scientific community of one country.

Шевченка. Політологія. 2017. № 1. С. 5-11; Вілков В.Ю. Ідеологема та міфологема «Національна ідея»: українська політико-філософська традиція в дискурсі сучасної теорії демократії (частина друга). Wspótpraca Europejska, 2018. № 5 (36). С. 9-22.

48 Вілков В.Ю. Генезис поняття нації. Видання 3-ге. Київ : Видавець Карпенко В.М., 2014. С. 231-255. 


\section{CONCLUSIONS}

There were several stages in the evolution of Russian and then Soviet Marxism, as well as in the series of attempts to reconsider and, as a result, modernize the theory of the nation. The first anti-Stalinist stage is considered to be the most unexpected and radical. It began under the influence of the Twentieth Congress of the CPSU (February 1956), after the report of Nikita Khrushchev at a non-public meeting devoted to the exposure of the personality cult of Joseph Stalin. The de-Stalinization measures in the political sphere began to be held in the very first months after the meeting of the Congress, however, in the sciences society the disclamation of Stalin's merit in creating the theory and concept of the nation, within and from the standpoint of the Marxist teaching, began at the beginning of the 1960s. In the publications of the late 50s, Stalin's ideas and works were still actively cited in a positive context. In scientific terms, his definition of the nation was highly appreciated, as well as the characteristics of its features. The abrupt change in assessments in the works of Soviet social science experts in national themes, the "de-Stalinization" of the theory of the nation itself and its "Leninization", became more active in the 1960s and actually ended by the mid-1970s. It can be considered the completion of the second stage of the renewal of the theory of the nation in Soviet Marxism. The first half of the 1980s is believed to be the third stage. The criticism of Stalin's theoretical ideas about the nation or his judgments and recommendations for conducting national policy (this problem disappeared from the discourse of social science in the USSR), was no longer its specific feature, but a diverse correction of the meanings of the basic elements/features of the national community, which representatives of various social sciences tried to implement.

Finally, it is necessary to recognize that the numerous scientific disputes and the second half of the 1970s, the first half of the 1980s of the twentieth century, were practically ineffectual. A scientific breakthrough in the radical renewal of the Marxist-Leninist, historical and economic theory of the nation, respectively, the meanings and senses of its concept, did not happen. The representatives of the social sciences were reconciled by a research attitude similar to the one that was announced 1970 as a result of a broad discussion of the 1960s ("Voprosy Istorii" journal: 1966, No 4, 6, 12; 1967, No 6-7; and finally number 8, 1970). They came to the conclusion that, "a detailed discussion during the debates confirmed the opinion of the majority" of Soviet scientists, that "the definition of the nation that we have (similar to Stalin. - V.V.) includes the main features of all types of nations"; it "is scientific, Marxist", "is a part of the Marxist-Leninist theory of the 
nation". And although such a definition "does not disclose the specific features of each" of the types of nations, however, "the accepted Marxist concept of the nation (with the exception of some clarifications) does not need to be reconsidered" 49 .

In general, despite its duration and a large number of participants who represented different branches of sociopolitical and humanitarian knowledge in the USSR, the discussion did not bring any fundamentally new scientific, theoretical or political significant results. Stalin played a "cruel joke" with the adherents of Marxism-Leninism when an unsolvable problem and dilemma arose. Rejection of the meanings of the Stalinist definition of the nation would inevitably mean the abandonment of the basic tenets of the Marxist theory of society and its history. And vice versa, the recognition of the scientific truth of the axiomatics of the Marxist theory of the historical process logically and naturally required such a definition of the national community with its main features, which would make it possible to introduce nothing more than a stylistic correction of the Stalin's formula.

In conclusion, if one concisely assesses the transformation of conceptual knowledge about nations, dominant cognitive attitudes among representatives of the scientific communities of the post-Soviet period, then it can be noted that since the early 1990s, as an alternative to the uniformity of the theoretical and ideological prescriptions of Marxist-Lenin metanaration, especially its historical economic theory of the nation, the authors "intellectual freedom" had appeared, more similar to a scientifictheoretical anarchy. Although at that time Soviet Marxism often remained an ideological foundation of social science, it did not transform the Stalinist interpretation of the nation radically, but its ideas were already actively, unsystematically, uncritically combined in symbiosis with individual postulates of those theories, paradigms or approaches, which were created by Western anti-Marxism researchers. Moreover, within the framework of academic and university science of the post-Soviet period, unlimited freedom to choose ideological bases for personal theoretical generalizations and constructions, complete nihilism in relation to the previous theoretical legacy (primarily Marxist), created an atmosphere of chaos of "points of view" in the subject field of the theory of the nation, stimulated scientific irresponsibility and strong tendencies to eclecticism, relativism, as well as to the substitution of independent and systematic analysis by compilations or by judgments deprived of any scientific specificity.

${ }^{49}$ Горовский Ф.Я., Римаренко Ю.И. Марксистско-ленинская теория нации и социалистическая практика. - К.: «Вища щкола», 1985. - С. 64-65. 


\section{SUMMARY}

For the first time in the post-Soviet period, in a separate publication, based on a concrete historical approach, the methods of systematic, comparative, discursive and content analysis, - the background, key ideas, theoretical and methodological foundations, ideological and political prescriptions of the Stalinist definition of the essence and attributes of the national community are analyzed and disclosed in detail, an assessment of its additions and comments to it is given. $(1913,1929)$. On the basis of the main principles of the Scientist research of the Soviet and foreign sources of the second half of the 20th, early 21 st centuries, typical problems of both, a critical review of the existing and newly created concepts of the nation (within the framework of Soviet Marxism of the 1960s-1980s and postSoviet Ukraine social and political studies), are revealed. In this context, it is shown how the permanent revision process of theoretical ideas on the national community was directly interrelated with the ideological functions of social and human sciences.

\section{REFERENCES}

1. Бауэр О. Национальный вопрос и социал-демократия. СанктПетербург, 1909. 600 с.

2. Бромлей Ю.В. Очерки теории этноса. Москва : Наука, 1983. $412 \mathrm{c}$.

3. Вилков В.Ю. Западная нациология XX столетия: концептуальные портреты. История теорий нации и национализма. Saarbrücken : Lambert Academic Publishing, 2014. 283 c.

4. Вилков В.Ю. Нации и национальная государственность. Очерки истории социально- и политико-философской мысли. Saarbrücken : Lambert Academic Publishing, 2017. 357 c.

5. Вілков В.Ю. Генезис поняття нації. Видання 3-те. Київ : Видавець Карпенко В.М., 2014. 372 с.

6. Вілков В.Ю. Ідеологема та міфологема «Національна ідея»: українська політико-філософська традиція в дискурсі сучасної теорії демократії (частина друга). Wspótpraca Europejska. Warszawa : Wydawca - Consilium Sp. z o.o., 2018. № 5 (36). C. 9-22.

7. Вілков В.Ю. Неоліберальна концепція нації та національнодержавного будівництва Вилла Кимлічки. Вісник Київського нащіонального університету імені Тараса Шевченка. Політологія. Київ : Видавничо-поліграфічний центр «Київський університет», 2017. № 1 (1). C. 5-11.

8. Глезерман Г.Е. Классы и нации. Москва : Политиздат, 1975.79 с. 
9. Горовський Ф.Я. Сталінське визначення нації. Мала енциклопедія етнодержавознавства. Київ : Довира : Генеза, 1996. C. 139.

10. Горовский Ф.Я., Римаренко Ю.И. Марксистско-ленинская теория нации и социалистическая практика. Київ : «Вища школа», 1985. $263 \mathrm{c}$.

11. Горовски, Ф.Я., Картунов А.В., Римаренко Ю.И. Нация. Межнациональные отношения. Термины и определения : Словарьсправочник. Київ, 1991. С. 45.

12. Горовський Ф., Картунов О., Римаренко Ю. Нація. Мала енциклопедія етнодержавознавства. Київ : Довира : Генеза, 1996. C. $121-122$.

13. Горовский Ф.Я., Картунов А.В., Римаренко Ю.И. Нація. Етнонаціональний розвиток України. Терміни, визначення, персоналії. Київ, 1993.800 с.

14. Данн О. Нации и национализм в Германии 1770-1990. СанктПетербург: «Наука», 2003. 467 с.

15. Дашдамиров А.Ф. Нация и личность. Баку : Элма, 1976. 226 с.

16. Иордан М.В. Национализм против интернационализма. Москва : Издательство «Наука», 1980. 264 с.

17. Калтахчян С.Т. Вступительная статья. Нация в истории и современности (Исследование в связи с историко-материалистической теорией нащии) / А. Козинг. Москва : Издательство «Прогресс», 1978. С. 5-22.

18. Калтахчян С.Т. Марксистско-ленинская теория нации и современность. Москва : Политиздат, 1983. 367 с.

19. Картунов О.В. Західні теорії етнічності, нації та націоналізму : навчальний посібник. Київ : Університет економіки та права «Крок», 2007. 192 c.

20. Картунов О.В. Вступ до етнополітології : навчальний посібник. Київ, 1999. 300 с.

21. Касьянов Г.В. Теорії нації та націоналізму : монографія. Київ : Либідь, 1999. 352 с.

22. Каутский К. Национализм и интернационализм. Петроград, 1918. C. 107.

23. Кимлічка В. Лібералізм і права меншин. Харків : Центр Освітніх Ініціатив, 2001. $176 \mathrm{c.}$

24. Козинг А. Нация в истории и современности (Исследование в связи с историко-материалистической теорией нации). Москва : Издательство «Прогресс», 1978. 291 с. 
25. Куличенко М.И. Национальные отношения в СССР и тенденции их развития. Москва : Мысль, 1972. $564 \mathrm{c}$.

26. Куц А.М. Взаимосвязь классовых и национальных отношений в развитом социалистическом обществе. Харьков : «Вища школа», 1982. $174 \mathrm{c}$.

27. Ленин В.И. К еврейским рабочим. Полн., собр., соч. Москва : Издательство политической литературы, 1979. Т. 10. С. 266-269.

28. Ленин В.И. Карл Марс. Полн. собр. соч. Москва : Издательство политической литературы, 1977. Т. 26. С. 43-93.

29. Межнациональные отношения. Термины и определения : Словарь справочник. Киев, 1991. 408 с.

30. Научный коммунизм : Учебник для вузов. 5-е изд. Москва : Политиздат, $1981.431 \mathrm{c.}$

31. Политология: Энциклопедический словарь. Москва : Изд-во Моск. коммерч. Ун-та, 1993. 431 с.

32. Політологичний енциклопедичний словник : навч. посібник для студентів вищ. навч. закладів. Київ : Генеза, 1997.400 с.

33. Сталин И.В. Марксизм и национальный вопрос. Сочинения. Москва : Государственное издательство политической литературы, 1951. T. 2. C. 290-367.

34. Сталин И.В. Национальный вопрос и ленинизм. Ответ товарищам Мешкову, Ковальчуку и другим. Сочинения. Москва : Государственное издательство политической литературы, 1952. Т. 11. C. 333-355.

35. Философский энциклопедический словарь. Москва : Сов. Энцикллопедия, $1983.840 \mathrm{c.}$

36. Шпринер Р. Национальные проблемы: Борьба национальностей в Австрии. Санкт-Петербург : Общественная польза, 1909. 293 с.

37. Smith A.D. Nationalism and Modernism. URL: http://milliyyet.info/ wp-content/uploads/2015/11/Anthony-D.-Smith-Nationalism-andModernism.pdf

\section{Information about author:} Vilkov V. Yu., $\mathrm{PhD}$ (Philosophy), Associate Professor, Senior Staff Scientist at Faculty of Philosophy Taras Shevchenko National University of Kyiv 64/13, Volodymyrska Str., Kyiv, Ukraine 